\title{
SIMULASI BEBAN LALU LINTAS JEMBATAN BENTANG 40 M DENGAN MENGGUNAKAN DATA WEIGH IN MOTION (WIM)
}

\author{
Mahathir $^{1}$, Made Suangga ${ }^{2}$ \\ ${ }^{1}$ Magister Teknik Sipil, Universitas Tarumanagara, Jakarta \\ Email: mahathir.thamrin@gmail.com \\ ${ }^{2}$ Magister Teknik Sipil, Universitas Tarumanagara, Jakarta \\ 2 Jurusan Teknik Sipil, Universitas Bina Nusantara, Jakarta \\ Email:suangga@binus.edu
}

Masuk: 17-07-2020, revisi: 27-08-2020, diterima untuk diterbitkan: 05-09-2020

\begin{abstract}
ABSTRAK
Teknologi pengukuran beban kendaraan terus berkembang dan salah satunya adalah teknologi pengukuran beban kendaraan bergerak weigh in motion (WIM). Teknologi weigh in motion (WIM) memungkinkan pengukuran beban kendaraan dilakukan saat kendaraan melintas, yang merupakan beban aktual lalu lintas yang diterima oleh jalan dan jembatan. Penelitian ini bertujuan membandingkan respons jembatan terhadap beban aktual lalu lintas dari data WIM dengan beban rencana Standar SNI 1725:2016. Jembatan yang diteliti adalah jembatan gelagar baja komposit bentang $40 \mathrm{~m}$, dengan menggunakan data WIM Jembatan Kaligawe Semarang. Berdasarkan karakteristik beban sumbu kendaraan, golongan 40 yaitu jenis kendaraan truk dua sumbu memiliki nilai beban sumbu terbesar 18 ton dengan persentase overload sebesar $80 \%$. Sedangkan berdasarkan karakteristik jumlah kendaraan, golongan 30 yaitu jenis kendaraan mobil dua sumbu memiliki jumlah kendaraan sebesar 2296. Hasil analisis 3D struktur jembatan dapat disimpulkan bahwa beban aktual lalu lintas data WIM Jembatan Kaligawe Semarang menghasilkan momen lentur dan gaya geser yang lebih rendah dari beban standar SNI 1725:2016. Nilai rasio momen lentur dan gaya geser maksimum beban aktual lalu lintas data WIM terhadap beban standar SNI 1725:2016 pada jembatan bentang 40 m berturut-turut adalah 0.93 dan 0.96. Hal ini menunjukan bahwa beban aktual lalu lintas data WIM memiliki beban yang lebih kecil dari beban standar SNI 1725:2016.
\end{abstract}

Kata Kunci: beban rencana kendaraan; jembatan; simulasi Monte Carlo; weight in motion

\begin{abstract}
Vehicle load measurement technology continues to develop and one of them is the weigh in motion (WIM) load measurement technology. Weigh in motion (WIM) technology allow the measurement of vehicle load when vehicles moving, which is the actual load of traffic received by road and bridge. This study aims to compare the response of the bridge to the actual load of traffic from the WIM data with the standard load of SNI 1725:2016. This study using a composite steel girder bridge span $40 \mathrm{~m}$, with WIM data of the Kaligawe Bridge in Semarang. Based on the characteristic of the vehicle axle load, class 40 namely the type of two-axle truck, has the largest axle load value 18 tons with an overload percentage $80 \%$. Whereas based on the characteristic of the vehicle amount, class 30 namely the type of two-axle car, has the largest vehicle amount of 2296. The result of the 3D analysis of the bridge structure can be concluded that the WIM traffic data at Kaligawe Bridge Semarang obtained bending moment and shear force lower than the standard load of SNI 1725:2016. The ratio value of the maximum bending moment and shear force of WIM data traffic load to standard load of SNI 1725:2016 on $40 \mathrm{~m}$ span bridge are 0.93 and 0.96. This shows that the actual load of WIM data traffic has a load that is smaller than the standard load of SNI 1725: 2016.
\end{abstract}

Keywords: bridge; design vehicle load; Monte Carlo simulation; weight in motion

\section{PENDAHULUAN}

\section{Latar Belakang}

Jembatan adalah suatu konstruksi yang berfungsi untuk menghubungkan dua bagian jalan yang terputus oleh adanya rintangan-rintangan seperti sungai, danau, saluran irigasi, jalan raya yang melintang dan lain-lain. Ada beberapa tipe jembatan yang diterapkan di Indonesia, salah satu yang paling banyak diterapkan adalah jembatan gelagar baja komposit. Jembatan gelagar baja komposit merupakan perpaduan bahan konstruksi baja dengan beton bertulang, dimana baja material yang 
kuat tarik diletakkan dibagian bawah jembatan berfungsi sebagai gelagar dan beton material yang kuat tekan ditempatkan diatas jembatan berfungsi sebagai plat lantai jembatan.

Jembatan di Indonesia dirancang dan didesain menggunakan standar pembebanan jembatan SNI 1725:2016, dimana beban-beban yang diatur dalam standar ini terdiri dari beban kendaraan, beban gempa, beban mati, dan beban angin. Beban kendaraan dalam peraturan ini merupakan idealilasi terhadap beban kendaraan sebenarnya. Volume lalu lintas dan berat kendaraan menjadi salah satu faktor dalam mendesain struktur jembatan. Volume lalu lintas dan beban kendaraan merupakan data primer yang pengumpulannya memerlukan ketelitian dan akurasi yang baik untuk mendapatkan hasil yang maksimal.

Teknologi pengukuran beban kendaraan konvensional yang umum digunakan adalah jembatan timbang statis. Jembatan timbang statis ini memerlukan kendaraan untuk diberhentikan terlebih dahulu untuk kemudian ditimbang secara statis. Hal ini tentunya dapat mengganggu kelancaran lalu lintas untuk ruas jalan yang lalu lintasnya padat. Penggunaan jembatan timbang statis kurang efisien, sehingga diperlukan adanya sistem pemilah beban yang dapat langsung menentukan beban ketika kendaraan melewati sensor beban pada kendaraan.

Teknologi pengukuran beban kendaraan terus berkembang dan salah satunya adalah teknologi pengukuran beban kendaraan bergerak weigh in motion (WIM). Teknologi WIM memungkinkan pengukuran beban kendaraan dilakukan saat kendaraan melintas, yang merupakan beban aktual lalu lintas yang diterima oleh jalan dan jembatan. Data yang dapat dikumpulkan dari WIM antara lain beban gandar (axle weight), beban total (gross weight), jarak antar gandar (axle spacing), klasifikasi kendaraan, dan kecepatan kendaraan.

Pada penelitian sebelumnya, telah dilakukan evaluasi reliabilitas jembatan standar Bina Marga kelas A dengan panjang bentang $25 \mathrm{~m}$ tipe gelagar beton bertulang dan tipe gelagar komposit terhadap data beban WIM di ruas jalan nasional Cikampek - Pamanukan pada tahun 2011. Temuan dari penelitian ini menunjukkan bahwa gaya dalam berupa momen lentur maksimum pada gelagar jembatan standar Bina Marga kelas A tipe komposit $25 \mathrm{~m}$ yang diakibatkan oleh beban nominal standar dalam peraturan RSNI T-02-2005: pembebanan untuk jembatan, lebih tinggi dari momen lentur maksimum akibat kombinasi beban terukur WIM di Jalur Pantura Cikampek Pamanukan (Nugraha dan Hardono, 2015).

\section{Tujuan Penelitian}

Tujuan dari penelitian ini adalah untuk mengetahui karakteristik aktual lalu lintas berdasarkan data WIM, membuat simulasi beban lalu lintas untuk bentang $40 \mathrm{~m}$, membandingkan gaya dalam akibat beban aktual lalu lintas dari data WIM terhadap beban rencana Standar SNI 1725:2016.

\section{METODE PENELITIAN}

Tipe struktur jembatan adalah jembatan gelagar baja komposit dengan bentang $40 \mathrm{~m}$. Struktur jembatan menggunakan lebar jembatan sembilan meter, potongan melintang struktur jembatan secara tiga dimensi dapat dilihat pada gambar 1. Analisis numerik akan dilakukan dengan menggunakan bantuan program finite element. 


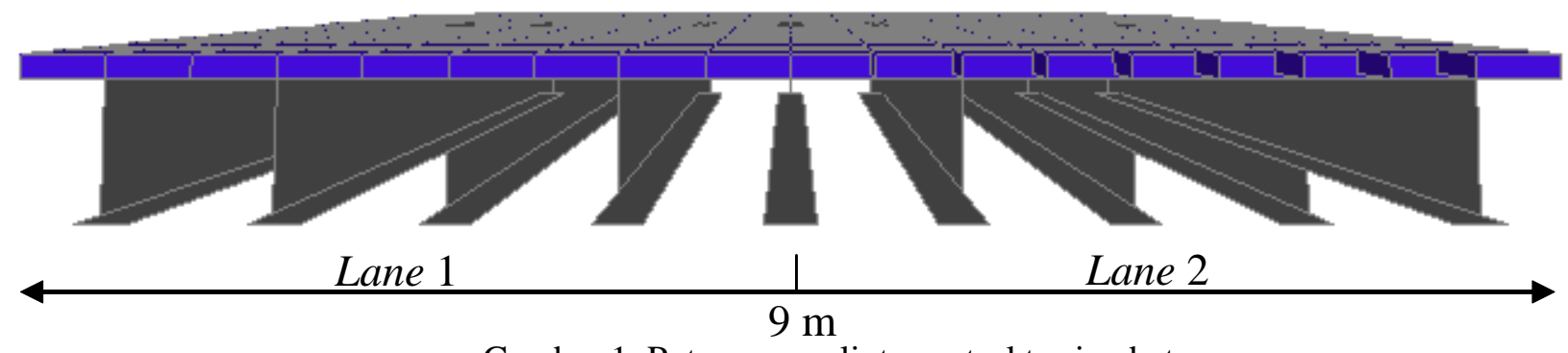

Gambar 1. Potongan melintang struktur jembatan

Sumber: Penulis, 2020

Penelitian dilaksanakan dengan menggunakan data WIM Jembatan Kaligawe Semarang oleh Pusat Penelitian dan Pengembangan Jalan dan Jembatan Kementrian Pekerjaan Umum dan Perumahan Rakyat selama 7 hari dari tanggal 1 - 7 November 2018. Jembatan Kaligawe merupakan jalan nasional yang terletak di Kel. Tambakrejo, Kec. Gayamsari, Kota Semarang.

Sebelum dianalisis, data harus difilter dahulu dikarenakan teknologi WIM dapat merekam pengukuran yang tidak akurat, misalnya dapat menafsirkan dua truk di jalur yang sama dengan satu rekaman atau satu truk dengan jarak antara dua as yang berdekatan direkam sebagai satu rekaman. Berikut beberapa kriteria dalam menentukan proses filtering data WIM pada jenis kendaraan truk (Portela, 2017):
a. GVW kurang dari 6.2 ton
b. Berat sumbu tunggal kurang dari 2.2 ton
c. Berat tandem lebih besar 32 ton
d. Jarak sumbu tandem kurang dari 0.92 meter
e. Total panjang lebih besar dari 36 meter
f. Truk panjang lebih besar dari 15.4 meter dan GVW kurang dari 10.4 ton
g. Berat sumbu tunggal lebih besar dari 18 ton
h. Selisih GVW dan penjumlahan berat sumbu sama atau lebih besar dengan $10 \%$.
i. Jumlah jarak sumbu berbeda dengan panjang total kendaraan
j. Total panjang kurang dari 5 meters
k. Kecepatan lebih besar dari $170 \mathrm{~km} / \mathrm{jam}$
1. Beban sumbu kemudi lebih besar dari 10 ton
m. GVW lebih besar dari 93 ton

Pengolahan data probabilistik dan statistik dilakukan dengan mengunakan bantuan EasyFit. Simulasi beban lalu lintas dilakukan dengan menggunakan metode Monte Carlo. Simulasi merupakan suatu teknik meniru operasi-operasi atau proses- proses yang terjadi dalam suatu sistem dengan bantuan perangkat komputer dan dilandasi oleh beberapa asumsi tertentu sehingga sistem tersebut bisa dipelajari secara ilmiah (Law and Kelton, 1991). Dengan melakukan studi simulasi maka dalam waktu singkat dapat ditentukan keputusan yang tepat serta dengan biaya yang tidak terlalu besar karena semuanya cukup dilakukan dengan computer.

Menurut Kakiay (2003), simulasi Monte Carlo dikenal juga dengan istilah sampling simulation atau Monte Carlo sampling technique. Sampling simulation ini menggambarkan kemungkinan penggunaan data sampel dalam metode Monte Carlo dan juga sudah dapat diketahui atau diperkirakan distribusinya. Simulasi ini menggunakan data yang sudah ada (historical data) yang sebenarnya dipakai pada simulasi untuk tujuan lain. Model simulasi apabila mengikutsertakan random dan sampling dengan distribusi probabilitas yang dapat diketahui dan ditentukan, maka cara simulasi Monte Carlo ini dapat dipergunakan. 
Teknik simulasi Monte Carlo terbagi atas lima langkah sederhana yaitu sebagai berikut (Wardana, 2014):

a. Menetapkan sebuah distribusi probabilitas

b. Membuat distribusi probabilitas kumulatif bagi setiap variabel

c. Menetapkan sebuah interval angka acak bagi setiap variabel

d. Membangkitkan angka acak yang sedang diteliti, dapat menggunakan program

komputer untuk membangkitkan angka acak

e. Mensimulasikan hasil experimen dengan memilih angka acak dari tabel angka acak kedalam interval angka acak yang telah ditentukan

\section{HASIL DAN PEMBAHASAN}

\section{Data Distribusi Beban}

Pada penelitian ini data WIM Jembatan Kaligawe terdiri dari 2 lane yaitu lane 1 dan lane 2. Hasil pengolahan data diketahui data lane 1 memiliki jumlah data yang lebih banyak serta variasi jenis golongan kendaraan yang lebih lengkap. Maka pada penelitian ini, analisis dan simulasi beban lalu lintas data WIM menggunakan data lane 1.

\section{Karakteristik Beban Sumbu Maksimum}

Karakteristik beban sumbu maksimum, persentase jumlah kendaraan overload serta persentase overload setiap kelas kendaraan dapat dilihat pada gambar 2, gambar 3, dan gambar 4.

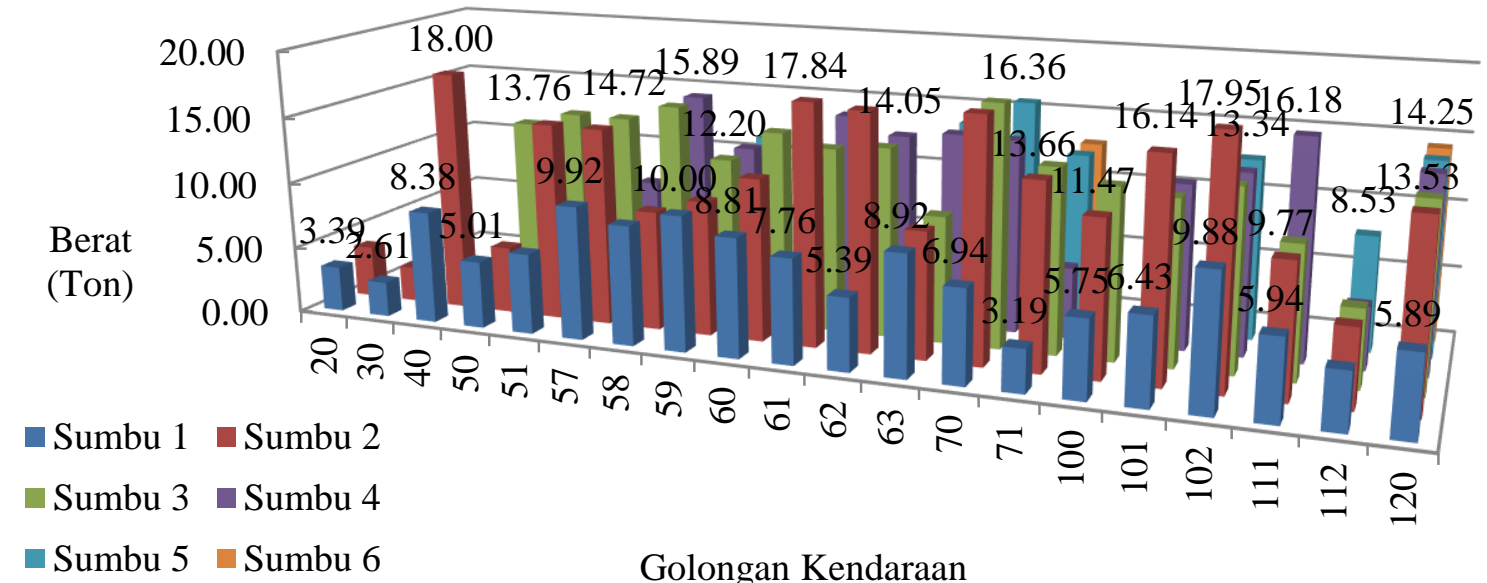

Gambar 2. Beban sumbu maksimum per kelas kendaraan Sumber: Penulis, 2020

Berdasarkan grafik diatas dapat diketahui bahwa nilai beban sumbu terbesar yaitu 18 ton pada golongan 40 merupakan jenis kendaraan truk dua sumbu. Sedangkan beban sumbu terkecil yaitu 2.61 ton pada golongan 30 merupakan jenis kendaraan mobil pengangkut barang. 


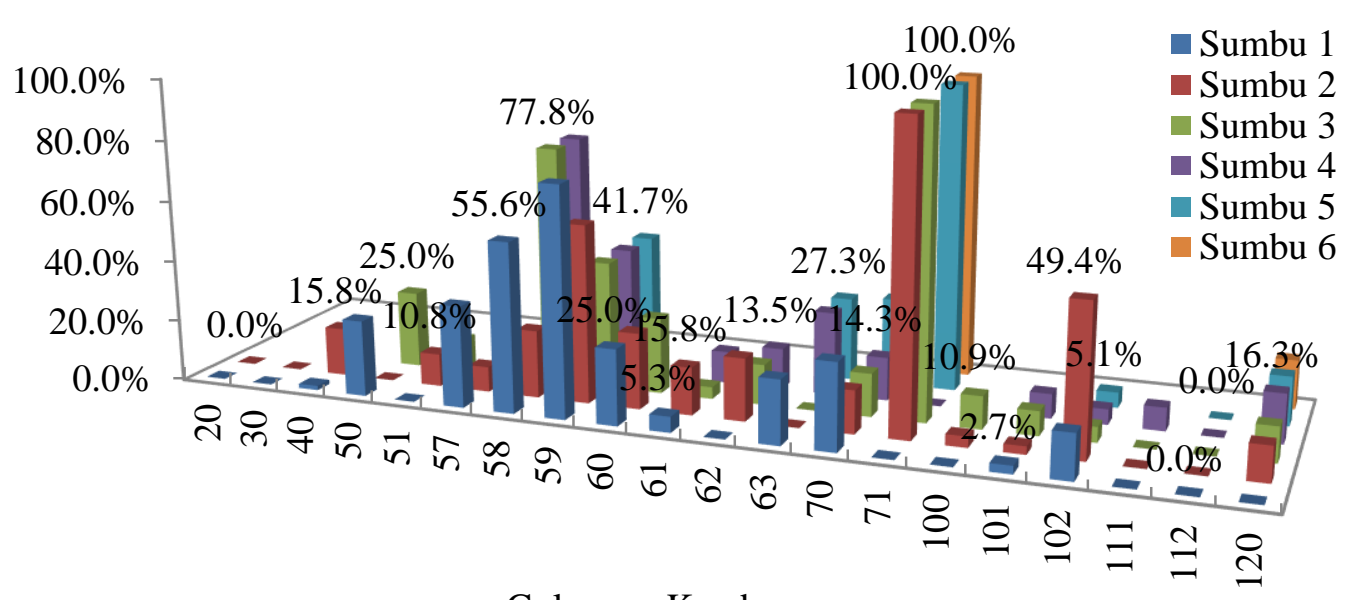

Golongan Kendaraan

Gambar 3. Persentase jumlah kendaraan overload

Sumber: Penulis, 2020

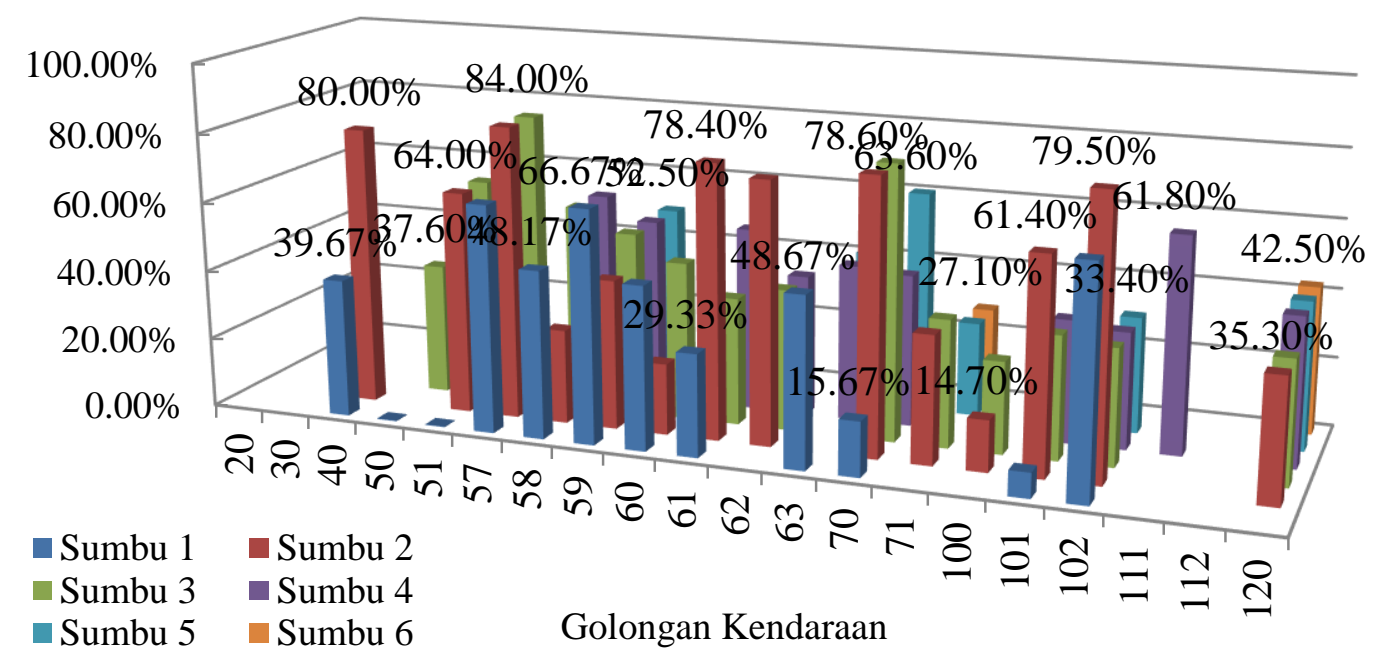

Gambar 4. Persentase overload

Sumber: Penulis, 2020

Berdasarkan grafik diatas dapat diketahui persentase jumlah kendaraan overload berkisar dari 0 $100 \%$. Sedangkan persentase overload berkisar dari $14-84 \%$. 


\section{Karakteristik Jumlah Kendaraan}

Karakteristik jumlah kendaraan setiap kelas kendaraan dapat dilihat pada gambar 5.

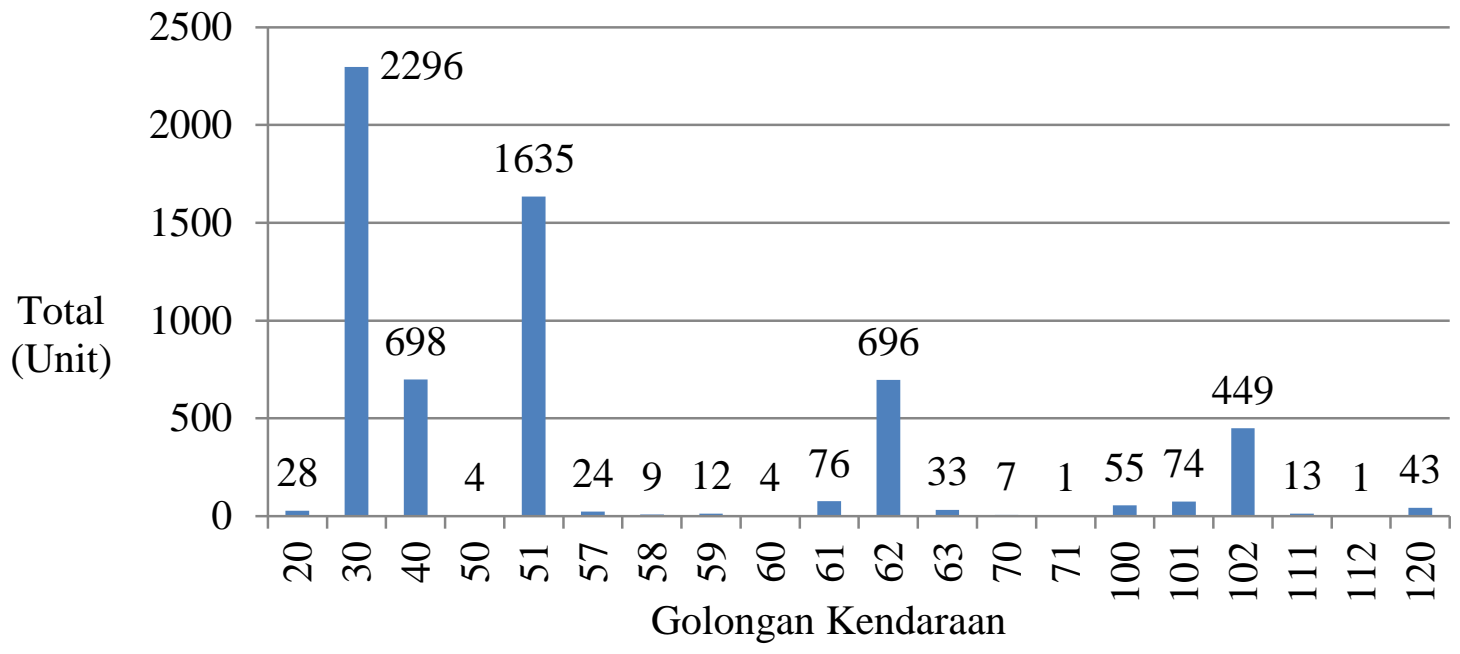

Gambar 5. Jumlah kendaraan per kelas kendaraan

Sumber: Penulis, 2020

Berdasarkan grafik diatas dapat diketahui bahwa jumlah kendaraan terbesar adalah golongan 30 yaitu jenis kendaraan mobil dua sumbu dengan jumlah kendaraan sebesar 2296.

\section{Simulasi Beban Lalu Lintas Data WIM}

Hasil perhitungan probabilitas kumulatif dan interval angka acak bagi setiap variabel golongan kendaraan dapat dilihat pada tabel 1.

Tabel 1. Probabilitas kumulatif dan interval angka acak bagi setiap variabel

\begin{tabular}{lccccc}
\hline No & $\begin{array}{c}\text { Golongan } \\
\text { Kendaraan }\end{array}$ & Frequensi & $\begin{array}{c}\text { Probability Density } \\
\text { Function (PDF) }\end{array}$ & $\begin{array}{c}\text { Cumulative Density } \\
\text { Function (CDF) }\end{array}$ & Tag Number \\
\hline 1 & 20 & 28 & 0.0045 & 0.0045 & $0.0000-0.0045$ \\
\hline 2 & 30 & 2296 & 0.3728 & 0.3774 & $0.0045-0.3774$ \\
\hline 3 & 40 & 698 & 0.1133 & 0.4907 & $0.3774-0.4907$ \\
\hline 4 & 50 & 4 & 0.0006 & 0.4914 & $0.4907-0.4914$ \\
\hline 5 & 51 & 1635 & 0.2655 & 0.7569 & $0.4914-0.7569$ \\
\hline 6 & 57 & 24 & 0.0039 & 0.7608 & $0.7569-0.7608$ \\
\hline 7 & 58 & 9 & 0.0015 & 0.7623 & $0.7608-0.7623$ \\
\hline 8 & 59 & 12 & 0.0019 & 0.7642 & $0.7623-0.7642$ \\
\hline 9 & 60 & 4 & 0.0006 & 0.7649 & $0.7642-0.7649$ \\
\hline 10 & 61 & 76 & 0.0123 & 0.7772 & $0.7649-0.7772$ \\
\hline 11 & 62 & 696 & 0.1130 & 0.8902 & $0.7772-0,8902$ \\
\hline 12 & 63 & 33 & 0.0054 & 0.8956 & $0,8902-0.8956$ \\
\hline 13 & 70 & 7 & 0.0011 & 0.8967 & $0.8956-0.8967$ \\
\hline 14 & 71 & 1 & 0.0002 & 0.8969 & $0.8967-0.8969$ \\
\hline 15 & 100 & 55 & 0.0089 & 0.9058 & $0.8969-0.9058$ \\
\hline
\end{tabular}




\begin{tabular}{cccccr}
\hline No & $\begin{array}{c}\text { Golongan } \\
\text { Kendaraan }\end{array}$ & Frequensi & $\begin{array}{c}\text { Probability Density } \\
\text { Function (PDF) }\end{array}$ & $\begin{array}{c}\text { Cumulative Density } \\
\text { Function (CDF) }\end{array}$ & Tag Number \\
\hline 16 & 101 & 74 & 0.0120 & 0.9178 & $0.9058-0.9178$ \\
\hline 17 & 102 & 449 & 0.0729 & 0.9907 & $0.9178-0.9907$ \\
\hline 18 & 111 & 13 & 0.0021 & 0.9929 & $0.9907-0.9929$ \\
\hline 19 & 112 & 1 & 0.0002 & 0.9930 & $0.9929-0.9930$ \\
\hline 20 & 120 & 43 & 0.0070 & 1.0000 & $0.9930-1.0000$ \\
\hline
\end{tabular}

Berdasarkan hasil hipotesis kompatibilitas (goodness of fit) metode uji Chi-Square diperoleh jenis distribusi yang sesuai yaitu distribusi Weibull (3P). Dengan menggunakan jenis distribusi Weibull (3P) akan dilakukan random number sebanyak 50 percobaan, kemudian mensimulasikan secara sederhana dengan memilih random number dari tabel angka acak. Urutan jenis kendaraan hasil simulasi dengan random number sebanyak 50 percobaan dapat dilihat pada tabel 2.

Tabel 2. Simulasi urutan jenis kendaraan pada 50 percobaan

\begin{tabular}{|c|c|c|c|c|c|}
\hline No & $\begin{array}{l}\text { Random } \\
\text { Number }\end{array}$ & $\begin{array}{c}\text { Kelas } \\
\text { Kendaraan } \\
\end{array}$ & No & $\begin{array}{l}\text { Random } \\
\text { Number }\end{array}$ & $\begin{array}{c}\text { Kelas } \\
\text { Kendaraan } \\
\end{array}$ \\
\hline 1 & 0.1226 & 30 & 26 & 0.6140 & 51 \\
\hline 2 & 0.2267 & 30 & 27 & 0.0185 & 30 \\
\hline 3 & 0.1849 & 30 & 28 & 0.7115 & 51 \\
\hline 4 & 0.1916 & 30 & 29 & 0.0241 & 30 \\
\hline 5 & 0.8689 & 62 & 30 & 0.2964 & 30 \\
\hline 6 & 0.6782 & 51 & 31 & 0.7095 & 51 \\
\hline 7 & 0.1434 & 30 & 32 & 0.1217 & 30 \\
\hline 8 & 0.2020 & 30 & 33 & 0.8397 & 62 \\
\hline 9 & 0.9613 & 102 & 34 & 0.9917 & 111 \\
\hline 10 & 0.2688 & 30 & 35 & 0.1242 & 30 \\
\hline 11 & 0.8021 & 62 & 36 & 0.6186 & 51 \\
\hline 12 & 0.3297 & 30 & 37 & 0.1658 & 30 \\
\hline 13 & 0.7042 & 51 & 38 & 0.3816 & 40 \\
\hline 14 & 0.8948 & 63 & 39 & 0.6044 & 51 \\
\hline 15 & 0.1788 & 30 & 40 & 0.2915 & 30 \\
\hline 16 & 0.1310 & 30 & 41 & 0.1784 & 30 \\
\hline 17 & 0.2551 & 30 & 42 & 0.9768 & 102 \\
\hline 18 & 0.8378 & 62 & 43 & 0.1979 & 30 \\
\hline 19 & 0.2267 & 30 & 44 & 0.1606 & 30 \\
\hline 20 & 0.7091 & 51 & 45 & 0.6163 & 51 \\
\hline 21 & 0.1260 & 30 & 46 & 0.2659 & 30 \\
\hline 22 & 0.1788 & 30 & 47 & 0.6015 & 51 \\
\hline 23 & 0.3184 & 30 & 48 & 0.6167 & 51 \\
\hline 24 & 0.3651 & 30 & 49 & 0.8726 & 62 \\
\hline 25 & 0.7209 & 51 & 50 & 0.6602 & 51 \\
\hline
\end{tabular}


Berdasarkan tabel diatas dapat kita ketahui golongan 30 dan 51 banyak ditemukan dalam suatu hasil simulasi, hal ini sesuai dengan nilai probabilitas golongan 30 dan 51 adalah sebesar $37.28 \%$ dan $26.55 \%$. Hasil simulasi diatas akan digunakan untuk membentuk beberapa kombinasi dengan batasan bentang jembatan $40 \mathrm{~m}$.

\section{Analisis 3D Struktur Jembatan}

Analisis struktur jembatan akan dianalisis dan dibandingkan nilai maksimum momen lentur dan gaya geser pada beban aktual lalu lintas data WIM terhadap standar beban lalu lintas jembatan Indonesia SNI 1725:2016. Kombinasi beban lalu lintas hasil simulasi data WIM akan diaplikasikan pada perhitungan struktur jembatan pada bentang $40 \mathrm{~m}$, dimana beban kendaraan data WIM yang dimasukkan dalam analisis menggunakan data beban maksimum hasil filterisasi. Berdasarkan hasil simulai beban lalu lintas data WIM untuk bentang $40 \mathrm{~m}$ diperoleh 11 kombinasi yang akan diaplikasikan ke struktur jembatan. Gambar iring- iringan kendaraan, input beban, diagram momen, momen lentur dan gaya geser maksimum data WIM dapat kita lihat pada gambar 6 dan gambar 7.

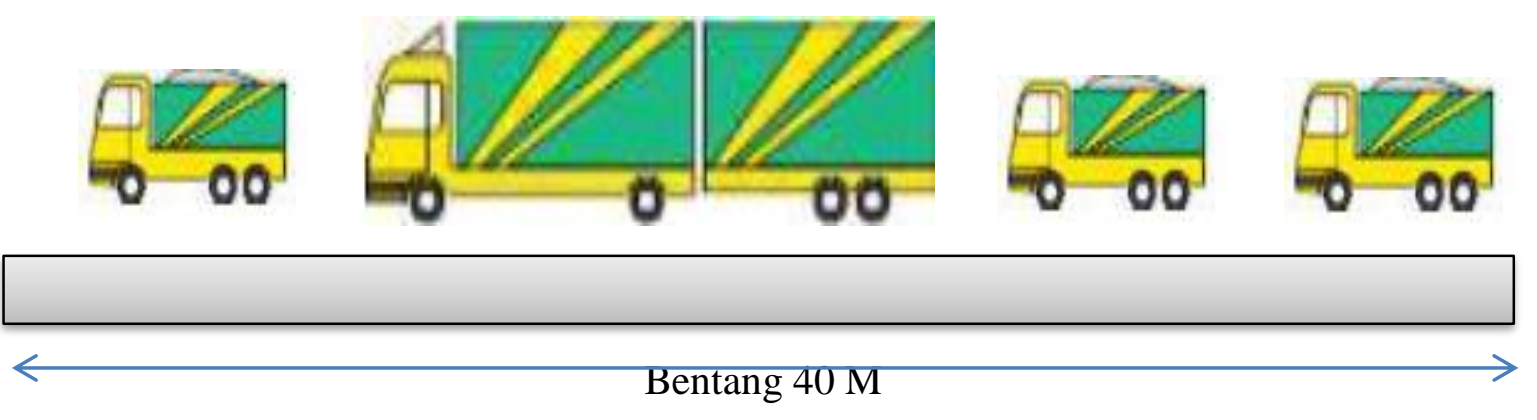

Gambar 6. Iring - iringan kendaraan

Sumber: Penulis, 2020
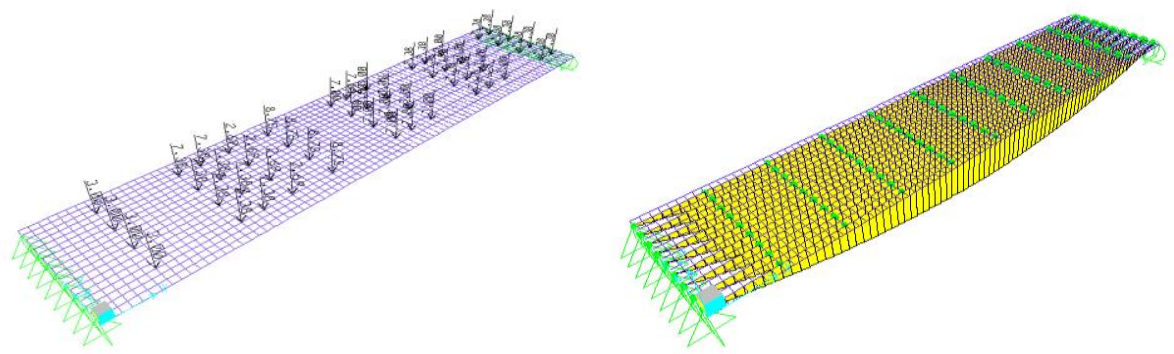

(a)Input beban sumbu kendaraan

(b) Diagram momen lentur jembatan

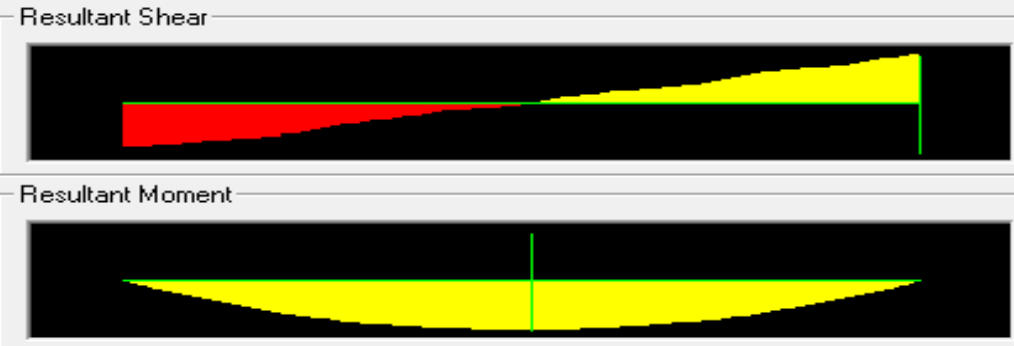

Shear $\mathbf{Y 2}$

28.7952 Tonf

at $40.00000 \mathrm{~m}$

(c) Momen lentur dan gaya geser maksimum jembatan

Gambar 7. Input beban, diagram momen, momen lentur dan gaya geser maksimum data WIM

Sumber: Penulis, 2020 
Berikut dapat kita lihat pada gambar 8 merupakan input beban lajur D (Standar SNI 1725:2016), diagram momen, momen lentur dan gaya geser maksimum.
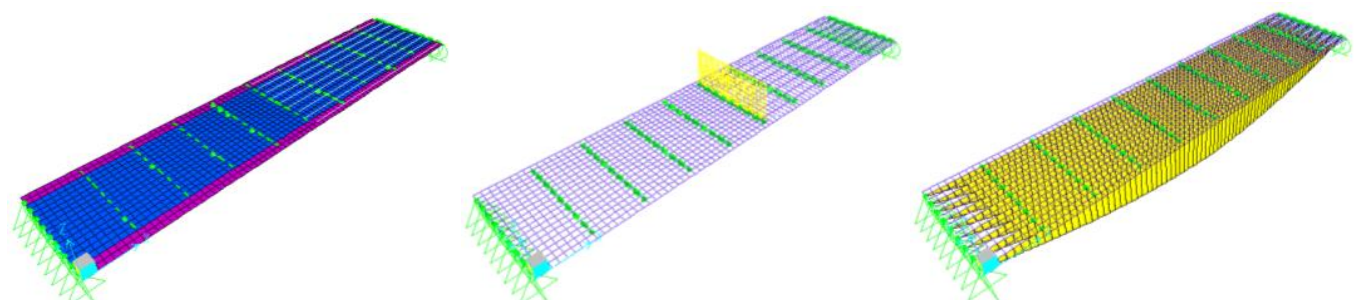

(a)Input beban BTR (b) Input Beban BGT (c) Diagram momen lentur jembatan

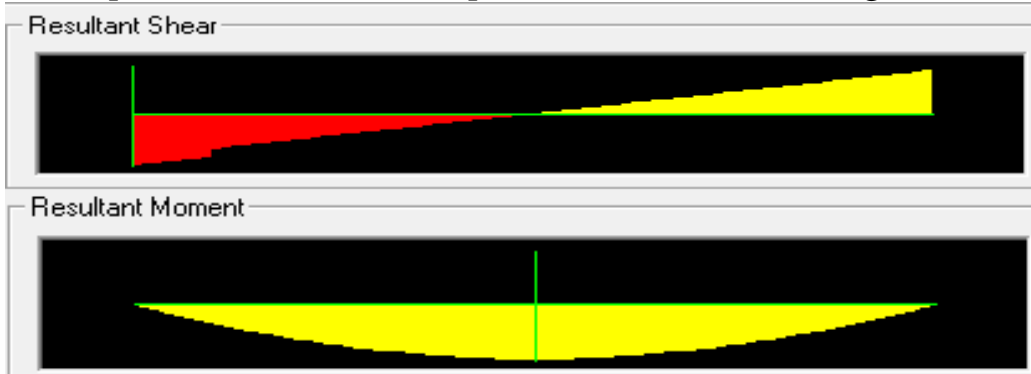

Shear $\mathbf{2}$

$-29.9003 \mathrm{Tonf}$

at $0.00000 \mathrm{~m}$

(d) Momen lentur dan gaya geser maksimum jembatan

Gambar 8.Input beban, diagram momen, momen lentur dan gaya geser maksimum beban lajur D Sumber: Penulis, 2020

Berikut dapat kita lihat pada gambar 9 merupakan input beban truk T (Standar SNI 1725:2016), diagram momen, momen lentur dan gaya geser maksimum.
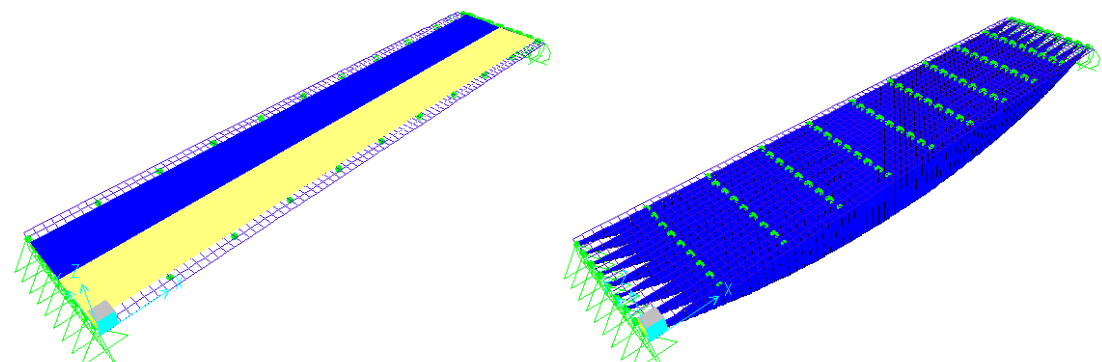

(a)Input beban T (moving load)

(b) Diagram momen lentur jembatan

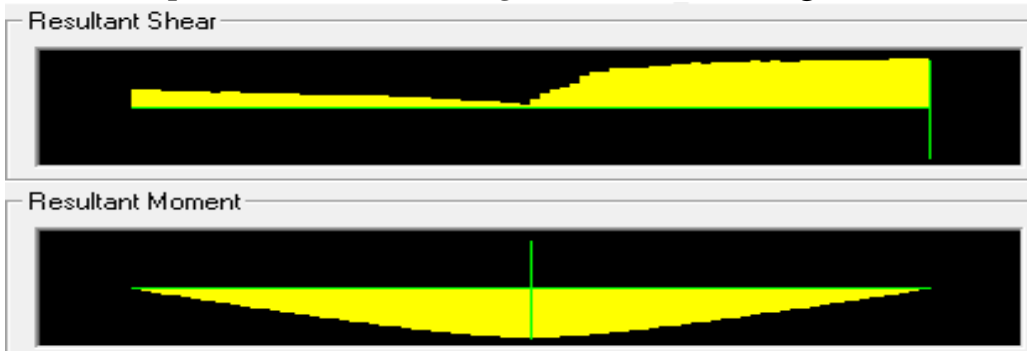

Shear $\mathbf{V} 2$

4.5017 Tonf

at $40.00000 \mathrm{~m}$

(c) Momen lentur dan gaya geser maksimum jembatan

Gambar 9.Input beban, diagram momen, momen lentur dan gaya geser maksimum beban truk $\mathrm{T}$

Sumber: Penulis, 2020 
Berdasarkan hasil analisis struktur diatas dapat diketahui bahwa nilai maksimum momen lentur dan gaya geser akibat beban aktual lalu lintas data WIM masing-masing adalah sebesar 197.73 Ton-m dan 28.79 Ton. Sedangkan nilai maksimum momen lentur dan gaya geser akibat beban standar SNI 1725:2016 berturut-turut adalah sebesar 211.82 Ton-m dan 29.9 Ton.

\section{Rasio Momen Lentur Dan Gaya Geser Maksimum}

Berikut pada tabel 3 dan tabel 4 dapat dilihat nilai maksimum dan rasio momen lentur dan gaya geser jembatan bentang $40 \mathrm{~m}$.

Tabel 3. Nilai maksimum momen lentur dan gaya geser jembatan

\begin{tabular}{ccc}
\hline Beban & Momen Lentur Maksimum (Ton-m) & Gaya Geser Maksimum (Ton) \\
\hline Data WIM & 197.73 & 28.79 \\
\hline SNI 1725:2016 & 211.82 & 29.90 \\
\hline
\end{tabular}

Tabel 4. Rasio momen lentur dan gaya geser jembatan

\begin{tabular}{ccc}
\hline Bentang & Rasio Momen WIM/SNI & Rasio Geser WIM/SNI \\
\hline 40 & 0.93 & 0.96 \\
\hline
\end{tabular}

Berdasarkan tabel diatas dapat kita ketahui bahwa beban aktual lalu lintas data WIM Jembatan Kaligawe Semarang menghasilkan momen lentur dan gaya geser yang lebih rendah dari beban standar SNI 1725:2016, dimana nilai rasio momen lentur dan gaya geser maksimum pada jembatan masing-masing sebesar 0.93 dan 0.96. Hal ini menunjukan bahwa beban aktual lalu lintas data WIM memiliki beban yang lebih kecil dari beban standar SNI 1725:2016.

\section{KESIMPULAN DAN SARAN}

\section{Kesimpulan}

Berdasarkan hasil penelitian dapat diambil beberapa kesimpulan sebagai berikut:

a. Berdasarkan karakteristik beban sumbu kendaraan, golongan 40 yaitu jenis kendaraan truk dua sumbu memiliki nilai beban sumbu terbesar 18 ton dengan persentase overload sebesar $80 \%$.

b. Berdasarkan karakteristik jumlah kendaraan, golongan 30 yaitu jenis kendaraan mobil dua sumbu memiliki jumlah kendaraan terbesar yakni 2296.

c. Berdasarkan hasil analisis probabilitas data WIM, golongan 30 dan 51 memiliki nilai probabilitas terbesar yaitu $37.28 \%$ dan $26.55 \%$, dimana jumlah kendaraan golongan 30 dan 51 adalah masing-masing sebanyak 2296 dan 1635 dari total jumlah kendaraan sebanyak 6158 kendaraan.

d. Berdasarkan hasil analisis 3D struktur jembatan dapat disimpulkan bahwa beban aktual lalu lintas data WIM Jembatan Kaligawe Semarang menghasilkan momen lentur dan gaya geser yang lebih rendah dari beban standar SNI 1725:2016.

e. Nilai rasio momen lentur dan gaya geser maksimum beban aktual lalu lintas data WIM terhadap beban standar SNI 1725:2016 pada jembatan $40 \mathrm{~m}$ berturut-turut sebesar 0.93 dan 0.96. Hal ini menunjukan bahwa beban aktual lalu lintas data WIM memiliki beban yang lebih kecil dari beban standar SNI 1725:2016. 


\section{Saran}

Berdasarkan hasil penelitian dapat diberikan beberapa saran sebagai berikut:
a. Perlu dilakukan penelitian mengenai kriteria filterisasi data WIM di Indonesia
b. Perlu dilakukan penelitan dengan mengambil data beban lalu lintas WIM pada lokasi lain dengan jumlah pengambilan data yang lebih banyak.
c. Perlu dilakukan penelitian dengan jembatan menerus dengan variasi bentang dan tipe jembatan rangka

\section{REFERENSI}

Kakiay, J.T. (2004). Dasar Teori Antrian Untuk Kehidupan Nyata. Andi Offset, Yogyakarta.

Law, A.M. dan Kelton, W.D. (1991). Simulation Modelling and Analysis. McGraw-Hill, New York.

Nugraha, W. dan Hardono, S. (2015). Evaluasi Reliabilitas Jembatan Standar Tipe Komposit Menggunakan Data Hasil Pengukuran Beban Kendaraan Bergerak. Widyariset, 1, 11-20.

Portela, E.L., Teixeira, R.M., Bittencourt, T.N., dan Nassfi, H. (2017). Single and multiple presence statistics for bridge live load based on weigh-in-motion data. Ibracon structures and materials journal, 6, 1163-1173.

Standar Nasional Indonesia Nomor 1725, (2016). Pembebanan untuk Jembatan. Badan Standarisasi Nasional, Jakarta.

Wardana, M. W., Farham H. S., Dan A. P. (2014). Pengendalian Persediaan Pada Kondisi Stokastik Dan Harga Bertingkat Menggunakan Simulasi. Spektrum Industri, 2, 113 - 247. 
SIMULASI BEBAN LALU LINTAS JEMBATAN BENTANG $40 \mathrm{M}$

DENGAN MENGGUNAKAN DATA WIM 